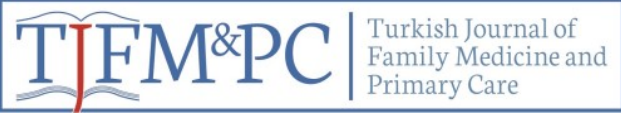

Original Research / Özgün Araştırma

\title{
Determining The Perspectives of Non-governmental Organizations on Child Labour and Children's Rights
}

\author{
Sivil Toplum Örgütlerinin Çocuk İşçiliğinde Çocuk Haklarına Yönelik Bakış Açılarının \\ Belirlenmesi
}

Emel Demir ${ }^{* 1}$, Erhan Yengil ${ }^{2}$

\begin{abstract}
Introduction: Child labour is a global issue including employers, families and children and involves multidisciplinary solutions. The aim of the study is to determine the relationship between the children rights and the point of view of non-govermental organization (NGO) workers on child labour. Material and Method: This prospective descriptive research study is accomplished in 4 months and carried out in 5 cities interviewing with 358 NGO workers cooperating with the UN International Children's Emergency Fund (UNICEF) and Confederation of Turkish Tradesmen (TESK). Sociodemographic information form, child labour survey questions and Child Rights Attitude Scale (CHTO) were used. Chi-square, Kolmogorov-Smirnov, Students's t-test, One Way ANOVA were used for data analysis and post-hoc LSD tests for advanced analysis. Results: Being an administrator, having education at university level, 11 years and more work experience increase the awareness of the employees of NGO's on child labour. The perspectives of employees on child labour were affected depending on gender, job position, work experience, age, education and place of residence. Their responsibility on children's rights was affected by male gender, university level education, being a manager, 26-35 age range and provinces. The data on the children rights education reveals that administrators and workers with bachelor degree participates more in to child rights related trainings. The mean ÇHTO score was found to be $33.79 \pm 10.65$ for the employees of NGO's and $36.43 \pm 12.25$ for leaders. Participants' attitudes on children's rights were affected in positive manner by being woman, 26-35 years of age, university graduation and residing in Adana province considering regionally. Conclusion: Socio-demographic characteristics, regional variations and training background of employees affect the NGO's workers' child rights attitude on child labour issues.
\end{abstract}

Keywords: Non-governmental Organizations, Child Labour, Child Rights, Pediatric Nursing, UNICEF

\section{ÖZET}

Giriş: Çocuk iş̧̧iliği, işveren, aile ve çocukları kapsayan küresel bir sorundur ve multidispliner çözümler içerir.Araştırmanın amacı sivil toplum örgütü çalışanlarının, çocuk iş̧̧iliğine yönelik bakış açılarının, çocuk hakları ile ilişkisini belirlemektir. Gereç ve Yöntem: Prospektif tanımlayıcı tipte yapılan araștırma, 4 ayda tamamlanmıștır. Birleșmiș Milletler Çocuklara Yardım Fonu (UNICEF) ve Esnaf ve Sanatkarlar Konfederasyonu (TESK) ișbirliği ile, 5 ilde 358 sivil toplum çalışanı ile yapılmıştır. Sosyodemografik bilgi formu, çocuk işçiliği anket soruları ve Çocuk Hakları Tutum Ölçeği (ÇHTÖ) kullanılmıştır. Veri analizi için SPSS programında ki-kare, Kolmogorov-Smirnov, Students's t-testi, OneWay ANOVA, ileri analizde post-hoc LSD testleri kullanılmıştır. Bulgular: Yönetici olmak, üniversite düzeyinde eğitim almak, 11 yıl ve üzerinde iş tecrübesine sahip olmak sivil toplum örgütleri çalıșanlarının çocuk ișçiliği farkındalık düzeylerini arttırmaktadır. Cinsiyet, iș pozisyonu, iș tecrübesi, yaş, eğitim ve ikamet edilen iller çalıșanların çocuk işçiliğine yönelik bakış açılarını etkilemektedir. Erkek cinsiyet, üniversite düzeyinde eğitim, yönetici olmak, 26-35 yaş aralı̆̆ı, iller gibi faktörler çocuk haklarının yaygınlaştırılmasında sorumluluk almayı etkilemektedir. Veriler çocuk haklarıyla ilgili eğitimlere, üniversite düzeyinde eğitim sahibi olanların ve yöneticilerin daha fazla katıldığını göstermektedir. Bu araştırmada sivil toplum örgütleri çalışanlarının ÇHTÖ puan ortalaması $33.79 \pm 10.65$, liderlerin puan ortalaması $36.43 \pm 12.25$ olarak bulunmuştur. Kadın olmak, 26-35 yaş aralığında olmak, üniversite mezunu olmak, sivil toplum örgütlerinin bölgesel olarak Adana ili katılımcıların çocuk hakları tutumlarını pozitif yönde etkilemektedir. Sonuç: Çocuk işçiliğinde, sosyodemografik özellikler, bölgesel farklılıklar ve çalışanların aldıkları eğitimler sivil toplum örgütleri çalışanlarının çocuk hakları tutumlarını etkilemektedir.

Anahtar Kelimeler: Sivil Toplum Örgütleri, Çocuk işçiliği, Çocuk Hakları, Çocuk Hemşireliği, UNICEF

Received date / Geliş tarihi: 21.08.2019, Accepted date / Kabul tarihi: 19.01.2020

${ }^{1}$ Hatay Mustafa Kemal University, Hatay Health School, Department of Pediatrics Nursing, HATAY-TÜRKIYE.

${ }^{2}$ Hatay Mustafa Kemal University, Tayfur Ata Sökmen Faculty of Medicine, Department of Family Practice, HATAY-TÜRKIYE.

*Address for Correspondence / Yazışma Adresi: Emel Demir, Hatay Mustafa Kemal University, Hatay Health School, Department of Pediatrics Nursing, HATAY-TÜRKIYE.

E-mail: emelteksoz@hotmail.com

Demir E, Yengil E. Sivil Toplum Örgütlerinin Çocuk İşçiliğinde Çocuk Haklarına Yönelik Bakış Açılarının Belirlenmesi. TJFMPC, 2020;14(1): 131-140.

DOI: $10.21763 / \mathrm{tjfmpc} .693159$ 


\section{GíRIŞ}

Çocuk işçiliği dünyada halen bir toplum sağlığ 1 problemi olarak devam etmektedir. ${ }^{1,2,3,4}$ Dünyada 5-17 yaş çalışan çocuk nüfusu 218 milyondur. Bu nüfusun 15-17 yaş grubunu içine alan 73 milyon çocuk işçi sağlık, güvenlik ve ahlaki gelişimlerini doğrudan tehlikeye atan, tehlikeli işlerde çalıştırılmaktadır. Çocuk işçilerin \%71'i tarım sektörü olmak üzere, \%17'si hizmet, \%12'si ağır çalışma koşulları içeren madencilik ve sanayi sektöründe yer almaktadır. Afrika'da her 5 çocuktan biri, Arap ülkelerinde 35 çocuktan biri, Avrupa'da 25 çocuktan biri, Asya ülkelerinde ve Amerika'da 14 çocuktan biri çocuk işçi olarak çalıştırılmaktadır. ${ }^{5}$

Türkiye'de 6-17 yaş grubunda 893 bin çocuk işçi bulunmaktadır. Türkiye'de çalışan çocukların \%44.7'si tarımda, \%31'i hizmet sektöründe ve \%24.3'ü sanayide çalışmaktadır. ${ }^{6}$ Türkiye'de $15-17$ yaş grubundaki her beş çocuktan biri çalışmakta, işgücüne katılma oranı \%21.1 olarak verilmektedir. ${ }^{7}$ Türkiye'de hala okul çağındaki çocukların yarısından fazlası, geçmiş yıllara oranla artarak işgücüne katılmaya devam etmektedir. ${ }^{8}$ Çocuk işçiliği üzerine yapılan araştırmalar çocukların büyüme ve gelişmesinin negatif etkilendiğine dikkati çekmektedir. ${ }^{2,9,10}$ Araştırmalar çalışan çocukların fiziksel sağlığına, çocuk işçiliğinin çocuk üzerindeki olumsuz psikolojik etkilerine ve eğitimlerinde aksamalara yol açtıklarını ortaya koymaktadır. ${ }^{2,11,12}$ Sosyal, ekonomik ve kültürel faktörleri içeren çocuk işçiliği dinamiğini, başta çocuklar olmak üzere, ebeveynler ve işverenler oluşturmaktadır. ${ }^{2,13,14}$ Çocuk işçilerin çalıştı̆̆ hizmet ve sanayi sektörü işveren olarak sivil toplum örgütlerinin yönetiminde yer almaktadır ve sivil toplum örgütlerine çocuk işçiliği konusunda yasal yaptırım ve dayanaklar sunmaktadır (ILO'nun 138 Sayılı Asgari Yaş Sözleşmesi, ILO’nun 182 Sayılı Sözleşme, 507 Sayılı Esnaf ve Sanatkârlar Kanunun madde 2). ${ }^{15}$

Çocukların sağlıklı büyüme ve gelişmesini vurgulayan çocuk hakları, çocuk işçiliği içinde geniş bir yer bulmaktadır. Çocuk işçilerin, sağlıklı büyüme ortamının ihlal edilmesi artan derecede, uluslararası endişe yaratan bir konudur. ${ }^{10,16}$ Yetişkin yaşına henüz erişmeyen, temel eğitim almamış çocuk nüfusunun istihdamı insan hakları, çocuk hakları ve pozitif hukuka aykırılık göstermesine rağmen yasal dayanaklar, çocukların fiziksel, zihinsel, sosyal ve psikolojik gelişimlerini en az düzeyde etkileyecek ortamlarda çalışmasına izin vermektedir. ${ }^{15,17}$ Uluslararası örgütler ve yerel sivil toplum örgütleri, ILO, UNICEF, UNESCO, AB, multidisipliner çalışmalara, uzun dönemli ve kapsamlı çalışmalara işaret etmektedir. ${ }^{4} \mathrm{Bu}$ bağlamda multidisipliner bir toplum sağlığı problemi olarak, çocuk işçiliğinde sivil toplum örgütlerinin bilgi ve tutumlarını belirleyecek araştırmalara gereksinim duyulmaktadır. Çocuk işçiliğinin farklı boyutlarıyla, kaliteli çalışmalar yapabilmek için, sağlık bakım profesyonellerinin bu konuda söz sahibi olan meslek üyeleriyle çalışması, multidisipliner yaklaşımın temelini oluşturmaktadır. ${ }^{111}$ Çocukların sağlık ve eğitimini etkilemeden, çocuk haklarını gözeten, çocuk işçiliğinde yapılacak düzenlemeler nispeten pozitif bir yaklaşım sayılabilir. ${ }^{10,14}$ Sivil toplum örgütlerinin pozitif yaklaşım içeren çocuk işçiliğine yönelik bilgi ve tutumları, çocukların iş koşullarını iyileştirmede belirleyici bir rol oynayabilir. Bu nedenle öncelikle, sivil toplum örgütleri liderlerinin çocuk işçiliği, çocuk hakları konusunda bakış açılarının ortaya koyan çalışmalara ihtiyaç duyulduğunu göstermektedir. $\mathrm{Bu}$ alanda yapılacak araştırma sonuçları, eksik ya da hatalı olarak tespit edilecek alanlarda çözüm üretmeye rehber olabilir. Araştırma sivil toplum örgütü çalışanlarının çocuk işçiliğine yönelik bakış açılarının çocuk hakları ile ilişskisini belirlemek amacıyla yapılmıştır.

\section{YÖNTEM}

\section{Araștırmanın Tipi, Zamanı ve Yeri}

Araştırma prospektif tanımlayıcı bir araştırmadır. Araştırma Mart-Haziran 2018 tarihleri arasında 4 ayda yapılmıştır.

Birleşmiş Milletler Çocuklara Yardım Fonu (UNICEF) Çocuk Hakları ve İş İlkeleri Programı kapsamında Türkiye Esnaf ve Sanatkarlar Konfederasyonu(TESK) işbirliği ile çocuk işçiliği konusunda işverenlerin bilgilendirilmesi amaciyla program 10 ilde (Ankara, Adana, Gaziantep, Hatay, İzmir, Malatya, Manisa, Mersin, Ordu ve Şanlıurfa) 1500 çalışan ve yöneticiyi kapsamaktadır. Araştırma örneklemi proje evreninden, büyükşehir olma özelliğine sahip 5 ilden 3'ü, katılımcı yoğunluğu ve daha yakın mesafede bulunması özellikleri dikkate alınarak belirlenmiştir. Örneklemi 5 ilde (Adana, Mersin, Ordu, Manisa, Ankara) toplam 358 kişi oluşturmuştur. Araştırma proje kapsamında davet edilerek toplantıya katılım sağlayan, gönüllü sivil toplum örgütü liderleri ve çalışanlarıyla yapılmıştır. 358 katılımcı sosyodemografik bilgi formu ve çocuk işçiliği anket sorularını cevaplarken, 275 katılımcı Çocuk Hakları Tutum Ölçeğine yanıt vermiştir.

\section{Veri Toplama Araçları}

Katılımc1lara sosyodemografik bilgi formu (7 soru), Çocuk işçiliği anket soruları (17 soru), Çocuk Hakları Tutum Ölçeği uygulanmıştır.

\section{Çocuk İşçiliği Anket Soruları}

Çocuk işçiliği anket soruları literatürde kullanılan anket sorularından alınmıştır. ${ }^{18}$ Anket katılımcıların çocuk işçiliğine bakış açılarını ölçmeye yönelik 17 sorudan oluşmaktadır. Katılımcıların "Evet", "Hayır" "Fikrim yok" seçeneklerinden biri cevap olarak kabul edilmiştir. Anketteki 1-6 arasındaki sorular 
katılımcıların çocuk işçiliğinde, çocuk hakları farkındalık düzeylerini ölçmeye yönelik sorulardan, 712 arasındaki sorular çocuk işçiliğine bakış açılarını ölçmeye yönelik sorulardan, 13-15 arasındaki sorular çocuk haklarının yaygınlaştırılması ve 16-17 arasındaki sorular katılımcıların bu konuda daha önceki faaliyetleri hakkında bilgilerini ölçen sorulardan oluşmaktadır.

\section{Çocuk Haklarına İlişkin Tutum Ölçeği}

\section{(ÇHÖ) Karaman Kepenekçi ${ }^{19}$ tarafından} geliştirilmiştir. Ölçeğin geçerlilik ve güvenirliği yine Karaman Kepenekçi ${ }^{19}$ tarafından yapılmış, ölçek tek faktörlü, toplam korelasyon katsayıları 0.32-0.61 arasında değişen ve Cronbach Alpha iç tutarlılık katsayısı 0.85 , yarı test güvenirlik katsayısı 0.77 olarak bildirilmiştir. Ölçek katılımcıların çocuk haklarına ilişkin tutumlarını belirlemek amacıyla yapılan 22 maddeden oluşmaktadır. Beşli likert tipinde cevaplar "Tamamen Katıliyorum", "Katıliyorum", "Kararsızım", "Katılmiyorum" ve "Tamamen Katılmiyorum" seçeneklerini içerir. Puanlama 1, 2, 3, 4, ve 5 şeklinde olup, ölçekten alınan puanın yüksek olması olumsuz tutumu göstermektedir. Ölçek sorularının 19'u olumlu, 3'ü olumsuz ifadeler olup 2., 14. ve 15 . maddeler ters puanlanmaktadır, toplam skor 22-110 arasındadır.

\section{Verilerin Değerlendirilmesi}

İstatistiksel değerlendirmeler için SPSS for Windows 22.0 (Statistical Package for Social Sciences) paket programı kullanıldı. Kategorik değişkenler arasındaki ilişki ki-kare testi ile değerlendirildi. Sürekli değişkenler normal dağılım yönünden KolmogorovSmirnov testi ile incelendi. Normal dağılım varsayımlarını sağladığı için iki grup ortalamasının karşılaştırılmasında Students's t-testi; ikiden fazla gruba ait ortalamanın karşılaştırılmasında OneWay ANOVA testi ve sonrasında post-hoc için varyanslar homojen olduğundan LSD testi kullanılmıştır. Tüm istatistiksel veriler için $\mathrm{p}<0.05$ anlamlı olarak kabul edildi.

\section{Araştırmanın Etik Yönü}

Araştırmanın, etik kurul izni Mustafa Kemal Üniversitesi'nden (2018/03) alınmıştır ve katılımcılardan sözlü ve yazılı onam alınmıştır.

\section{Araştırmanın Sınırlılıkları}

Araştırma 5 ildeki örneklem ile sınırlıdır, ulusal ve uluslararası genellemelerde bu veriler ön veri niteliğinde kullanılabilir. Ayrıca tüm katılımcılar bütün soruları cevaplamamıştır.

\section{Finansal destek}

$\mathrm{Bu}$ araştırma Türkiye Esnaf Sanatkarlar Konfederasyonu (TESK) ve UNICEF tarafindan desteklenmiştir.

\section{BULGULAR}

Araştırmanın sosyo-demografikverileri Tablo 1 'de verilmiştir.

\begin{tabular}{|clll|}
\hline Tablo 1. Sosyo-demografik veriler & & \\
\hline Gruplar (n) & & Sayı (n) & Yüzde (\%) \\
\hline Cinsiyet (358) & Erkek & 257 & 71.8 \\
& Kadın & 101 & 28.2 \\
\multirow{2}{*}{ İş (358) } & Başkan & 164 & 45.8 \\
& Çalışan & 194 & 54.2 \\
Tecrübe (358) & $0-5$ yıl & 69 & 19.3 \\
& 6-10 yıl & 49 & 13.7 \\
& $11+$ yıl & 240 & 67.0 \\
Yaş (358) & $18-25$ yaş & 14 & 3.9 \\
& 26-35 yaş & 61 & 17.0 \\
& $36-45$ yaş & 127 & 35.5 \\
& $46-56$ yaş & 156 & 43.6 \\
İller (358) & Adana & 54 & 15.1 \\
& Mersin & 115 & 32.1 \\
& Manisa & 73 & 20.4 \\
& Ordu & 59 & 16.5 \\
& Ankara & 57 & 15.9 \\
Eğitim durumu (358) & İlköğretim & 80 & 22.3 \\
& Lise & 139 & 38.8 \\
& Üniversite & 139 & 38.8 \\
\hline
\end{tabular}


Katılımcıların 1-6 arasındaki sorulara verdiği cevaplar, çocuk işçiliğinde çocuk hakları farkındalık düzeylerini ölçmeye yöneliktir. "Bölgenizde en kötü şartlardaki çocuk işçiliğinin biçimi ve çocuk haklarının neler olduğu konusunda bilginiz var mi?" sorusuna cinsiyet, yaş, iş tecrübesi, işteki pozisyonu ve illere göre istatistiksel olarak benzer yanıtlar verilmiştir $(p>0.05)$. Eğitim durumuna göre ilköğretim mezunu katılımcıların $\% 22.1$ 'i (47), lise mezunlarının \%32.4'ü (69), üniversite mezunlarının \%45.5'i (97) "Evet" yanıtını vermiştir, üniversite mezunları lehine istatiksel olarak anlamlıdır $(\mathrm{p}=0.012)$.

“Türkiye'de çocuk işçiliğiyle ilgili 4857 sayılı iş kanununda çocukların çalışma koşulları, işverenin ve devletin yükümlülükleri ve ilgili yönetmelikleri hakkındabilginiz var mi?" sorusuna cinsiyet, yaş, iş tecrübesi ve illere göre benzer yanıtlar verilmiştir (p>0.05). İş pozisyonunda yöneticilerin \%48.7'si (76), çalışanların \%51.3'ü (80) "Evet" yanıtını vermiştir, aradaki yöneticiler lehine istatiksel olarak anlamlıdır $(p=0.025)$. Eğitim durumuna göre ilk öğretim mezunu katılımciların \%22.4'ü (35), lisede \%25'i (39), üniversite mezunlarının \%52.6's1 (82) "Evet" yanıtını vermiştir $(\mathrm{p}<0.001)$.

"Bölgenizde çocuk işçiliğinin en yoğun olduğu sektörler konusunda bilginiz var mi?" sorusuna cinsiyet,yaş ve ișteki pozisyonuna göre benzer yanıtlar verilmiştir $(\mathrm{p}>0.05)$. İş tecrübesine göre dağılım $0-5$ y1lda \%14.8 (33), 6-10 yılda \%12.6 (28), 11 y1l ve üzerinde \%72.6 (162) "Evet" olarak belirlenmiştir, 11 y1l ve üzerinde çalışanlar lehine istatiksel olarak anlamlidır $(\mathrm{p}=0.001)$.

Eğitim durumuna göre ilköğretim mezunu katılımciların \%20.2'si (45), lise mezunlarının \%35.4'ü (79), üniversite mezunlarının \%44.4'ü (99) "Evet" yanıtını vermiştir, üniversite mezunları lehine istatiksel olarak anlamlıdır ( $\mathrm{p}=0.048)$. İllere göre "Evet" yanıtını verenlerin \%10.8'I (24) Adana, \%37.7'si Mersin (84), \%22'si Manisa (49), \%15.7'si Ordu (35), \%13.9'u Ankara (31) katılımcılardır, Mersin'deki katılımcılar lehine istatiksel olarak anlamlıdır $(\mathrm{p}=0.005)$.

“Uluslararası çalışma örgütü “ilo” nun '138've '182' nolu çocuk işçi çalıştırılmasıyla ilgili sözleşmeleri ile birleşmiş milletlerin 'çocuk hakları sözleşmesi've 'çocuk haklarl bildirgesi' hakkında bilginiz var $m \imath$ ?" "sorusuna cinsiyet, yaş, iş tecrübesi, işteki pozisyonu ve illere göre benzer yanıtlar verilmiştir $(\mathrm{p}>0.05)$.

Eğitim durumuna görei lköğretim mezunu katılımciların \%22.2'si (24), lise mezunlarının \%19.4'ü (21), üniversite mezunlarının \%58.3'ü (63) "Evet" yanıtını vermiştir, üniversite mezunları lehinei statiksel olarak anlamlıdır $(\mathrm{p}<0.001)$.
“Türkiye'de çocuk işçiliğinin nedenleri oluştuğu hakkında bilgi sahibi misiniz?" sorusuna cinsiyet, yaș, iş tecrübesi, işteki pozisyonuna göre benzer yanıtlar verilmiştir( $p>0.05)$. Eğitim durumuna görei lköğretim mezunu katılımcıların \%19.6'sı (47), lise mezunlarının \%34.2'si (82), üniversite mezunlarının \%46.3'ü (111) "Evet" yanıtını vermiştir, üniversite mezunları lehine istatiksel olarak anlamlıdır ( $\mathrm{p}=0.001)$. İllere göre "Evet" yanıtını verenlerin \%14.2'si (34) Adana, \%37.5'i Mersin (90), \%22.5'i Manisa (54), \%11.3'ü Ordu (27), \%14.6'sı Ankara (35) katılımcılardır, Mersin'deki katılımcılar lehine istatiksel olarak anlamlıdır $(\mathrm{p}=0.002)$.

"En kötü biçimlerdeki çocuk işçiliğinin nedenleri konusunda bilgi sahibi misiniz?" sorusuna cinsiyet, iş tecrübesi, işteki pozisyonuna göre benzer yanıtlar verilmiştir $(\mathrm{p}>0.05)$. Yaş dağılımına göre $18-25$ yaş grubundakilerin \%4.8'i (9), 26-35 yaş grubundakilerin \%21.2'si (40), 36-45 yaş grubundakilerin \%29.6's1 (56), 46-56 yaş grubundakilerin \%44.4'ü (84) "Evet" yanıtını vermiştir, 46-56 yaş lehine istatiksel olarak anlamlıdır $(\mathrm{p}=0.01)$. Eğitim durumuna göre ilköğretim mezunu katılımcıların \%21.2'si (40), lise mezunlarının \%32.3'ü (61), üniversite mezunlarının \%46.6's1 (88) "Evet" yanıtını vermiştir, üniversite mezunları lehine istatiksel olarak anlamlıdır $(\mathrm{p}=0.004)$. İllere göre "Evet" yanıtını verenlerin \%15.9'u (30) Adana, \%34.9'u Mersin (66), \%21.2'si Manisa (40), \%13.2'si Ordu (25), \%14.8'i Ankara (28) katılımcılardır, Mersin'deki katılımcılar lehine istatiksel olarak anlamlıdır $(\mathrm{p}=0.018)$.

7-13 arasındaki sorular, katılımcıların çocuk işçiliği hakkında bakış açılarını ölçmeye yöneliktir. "Çocuklar okula gitmek yerine küçük yaşlarda çalışmaya başlayarak daha yararl beceriler edinirler." sorusuna yaş, eğitim ve illere göre benzer yanıtlar verilmiştir $(\mathrm{p}>0.05)$. Cinsiyete göre erkeklerin \%86.2'si (50), kadınların \%13.8'i (8) "Evet" yanıtını vermiştir, erkekler lehine istatiksel olarak anlamlıdır $(\mathrm{p}=0.024)$. İş pozisyonuna göre yöneticilerin \%63.8'i (37), çalışanların \%36.2'si (21) "Evet" yanıtını vermiştir, yöneticiler lehine istatiksel olarak anlamlıdır $(\mathrm{p}=0.004)$. İş tecrübesine göre dağılıma göre, $0-5$ yıl arası tecrübesi olanların \%13.8'i (8), 6-10 yıl grubunun \%10.3'ü (6), 11 yıl ve üzerinde tecrübesi olanların \%75.9'u (44) "Evet" yanıtını vermiştir, 11 yıl ve üzerinde çalışanlar lehine istatiksel olarak anlamlıdır $(\mathrm{p}=0.045)$.

"15 yaşından küçük çocuklar hafif ev işleri dışında hiçbir şekilde çalıştırılmamalıdır." sorusuna cinsiyet, yaş, iş tecrübesi, işteki pozisyonu ve illere göre benzer yanıtlar verilmiştir $(p>0.05)$. Eğitim durumuna göre ilköğretim mezunu katılımcıların \%22.4'ü (57), lise mezunlarının \%43.3'ü (110), üniversite mezunlarının \%34.3'ü (87) "Evet” yanıtını vermiștir, lise mezunları lehine istatiksel olarak anlamlıdır $(\mathrm{p}=0.019)$. 
"Erken yaşlarda çalışmaya başlayan çocuk hayatı daha iyi öğrenir." Sorusuna iş tecrübesi, işteki pozisyonu ve illere göre benzer yanıtlar verilmiştir $(\mathrm{p}>0.05)$. Cinsiyete göre erkeklerin\%80.1'i (117), kadınların \%19.9'u (29) "Evet" yanıtını vermiştir, erkekler lehine istatiksel olarak anlamlıdır $(\mathrm{p}=0.009)$. Yaş dağılımına göre 18-25 yaş \%2.1'i (3), 26-35 yaşın \%15.1'i (22), 36-45 yaşın \%29.5'i (43), 46-56 yaşın \%53.4'ü (78) "Evet" yanıtını vermiştir, 46-56 yaş lehine istatiksel olarak anlamlıdır ( $\mathrm{p}=0.028)$. Eğitim durumuna göre ilköğretim mezunu katılımcıların \%32.2'si (47), lise mezunlarının \%40.4'ü (59), üniversite mezunlarının \%27.4'ü (40) "Evet" yanıtını vermiştir, lise mezunları lehine istatiksel olarak anlamlıdır $(\mathrm{p}<0.001)$.

“Ben küçük yaşlarda çalışlyordum, o da çalışmall." Sorusuna cinsiyet, yaş, iş tecrübesi, eğitim ve illere göre benzer yanıtlar verilmiştir $(\mathrm{p}>0.05)$. İş pozisyonuna göre yöneticilerin \%59.7'si (40), çalışanların \%40.3'ü (27) "Evet" yanıtını vermiştir, yöneticiler lehine istatiksel olarak anlamlıdır $(\mathrm{p}=0.033)$.

"Sokakta çalışan çocuğun okuldaki başarısı düşer, fiziksel ve zihinsel gelişimi olumsuz etkilenir. bu da çocuğun gelecekteki hayatını riske sokar." Sorusuna cinsiyet, yaş, iş tecrübesi ve eğitim durumuna göre benzer yanıtlar verilmiştir $(\mathrm{p}>0.05)$. İş pozisyonunda yöneticilerin \%42.9'u (123), çalışanların \%57.1'i (164) "Evet" yanıtını vermiştir, yöneticiler lehine istatiksel olarak anlamlıdır $(\mathrm{p}=0.052)$. İllere göre "Evet" yanıtını verenlerin \%13.2'si (38) Adana, \%35.2Si Mersin (101), \%20.9'u Manisa (60), \%15.7'si Ordu (45), \%15'i Ankara'daki (43) katılımcılardır, Mersin'deki katılımcılar lehine istatiksel olarak anlamlıdır $(\mathrm{p}=0.003)$.

Çocuk işçiliği anketi "Ăgaç yaşken ĕgilir, meslek erken yaşlarda öğrenilir.” Sorusuna cinsiyet, yaş, eğitim, işteki pozisyonu ve illere göre benzer yantlar verilmiştir $(\mathrm{p}>0.05)$. İş tecrübesine göre dağılım 0-5 yılda \%16.7 (38), 6-10 yılda \%13.2 (30), 11 yılveüzerinde \%70 (159) "Evet" olarak belirlenmiştir, 11 yıl ve üzerinde çalışanlar lehine istatiksel olarak anlamlidir $(\mathrm{p}=0.027)$.

"Çocuk işçiliği ve hakları konusunda toplumsal duyarlılı̆̆ arttırmak için; gazetelerde, dergilerdeve internet ortamında çeşitli bilgilendirici yazllar bulunmalı." Sorusuna yaş, iş tecrübesi, işteki pozisyonuna göre benzer yanıtlar verilmiştir ( $p>0.05)$. Cinsiyete göre erkeklerin \%70.3'ü (239), kadınların \%29.7'si (101) "Evet" yanıtını vermiştir, erkekler lehine istatiksel olarak anlamlıdır $(\mathrm{p}=0.024)$. İlere göre "Evet" yanitını verenlerin \%15'i (51) Adana, \%32.9'u Mersin (112), \%20.9'u Manisa (71), \%15.3'ü Ordu (52), \%15.9'u Ankara'daki (54) katılımcilardır, Mersin'deki katılımcilar lehine istatiksel olarak anlamlıdır ( $\mathrm{p}=0.006)$. Eğitim durumuna göre ilköğretim mezunu katılımcıların \%21.5'i (73), lise mezunlarının \%38.2'si (130), üniversite mezunlarının \%40.3'ü (137)
"Evet" yanıtını vermiştir, üniversite mezunları lehine istatiksel olarak anlamlidir $(\mathrm{p}=0.005)$.

Katılımcıların 14-15 arasındaki sorulara verdiği cevaplar çocuk haklarının yaygınlaştırılmasına yöneliktir. "Türkiye'deki çocuk işçiliği ve haklarl konusunda farkındalığının arttırllmasını, toplumsal bir vatandaşlık görevi olarak görüyorum, bunun için kendimi sorumlu hissediyorum. "sorusuna cinsiyet, yaş, iş tecrübesi, işteki pozisyonu ve eğitim durumuna göre benzer yanıtlar verilmiştir ( $p>0.05)$. İllere göre "Evet" yanıtını verenlerin \%15.8'i (53) Adana, \%34.3'ü Mersin (115), \%20.3'ü Manisa (47), \%14'ü Ordu (47), \%15.5'i Ankara'daki (52) katılımcılardır, Mersindeki katılımcılar lehine istatiksel olarak anlamlıdır $(\mathrm{p}<0.001)$.

"Çocuk işçiliği ve hakları konusunda toplumu bilgilendirici seminerler ve eğitimler yaygınlaştırılmalıdır." sorusuna cinsiyet, yaş, iş tecrübesi ve işteki pozisyonuna göre benzer yanıtlar verilmiştir $(p>0.05)$. Eğitim durumuna göre ilköğretim mezunu katılımcıların \%21.3'ü (73), lise mezunlarınn \%39.1'i (134), üniversite mezunlarının \%39.7'si (136) "Evet" yanıtını vermiştir, üniversite mezunları lehine istatiksel olarak anlamlıdır ( $\mathrm{p}=0.022)$. İllere göre "Evet" yanıtını verenlerin \%15.5'i Adana (53), \%33.2'si Mersin (114), \%20.4'ü Manisa (70), \%15.2'si Ordu (52), \%15.7'si Ankara'daki (54) katılımcılardır, Mersindeki katılımcilar lehine istatiksel olarak anlamlidir $(\mathrm{p}=0.022)$.

Katılımcıların 16-17 arasındaki sorulara verdiği cevaplar katılımciların bu konuda daha önceki faaliyetleri hakkındaki sorulardır. "Bu konuda daha önce yapılmış faaliyetler hakkında bilginiz var mı?" sorusuna verilen cevaplar bulunmuştur. "Bu konuda daha önce eğitime katıldınız mı?" sorusuna cinsiyet, yaş, iş tecrübesi ve illere göre benzer yanıtlar verilmiştir $(\mathrm{p}>0.05)$.Eğitim durumuna göre ilköğretim mezunu katılımcıların \%21.4'ü (18), lise mezunlarının \%32.1' $\mathrm{i}$ (27), üniversite mezunlarının \%46.4'ü (39) "Evet" yanıtını vermiştir, üniversite mezunları lehine istatiksel olarak anlamlıdır $\quad(\mathrm{p}=0.012)$. İş pozisyonunda yöneticilerin \%46.4'ü (39), çalışanların \%53.6's1 (45) "Evet" yanıtını vermiştir, yöneticiler lehine istatiksel olarak anlamlıdır $(\mathrm{p}=0.014)$.

Araştırmanın ÇHTÖ puanları Tablo 2'de, ilerianaliz alt grup sonuçları Tablo 3'de verilmiştir. Bu verilerine göre erkeklerin ÇHTÖ puan ortalaması $36.12 \pm 12.14$, kadınların $32.23 \pm 9.10$ olarak bulunmuştur, istatistiksel olarak kadınlar lehine anlamlıdır $(\mathrm{p}<0.01)$. Katılımcıların yaş dağılımına göre $18-25$ yaş ÇHTÖ puan ortalaması $31.67 \pm 9.45,26-35$ yaş için puan ortalaması $31.48 \pm 9.15,36-45$ yaş için puan ortalaması $34.08 \pm 11.29$, 46-56 yaş için puan ortalaması $37.88 \pm 12.09$ olarak bulunmuştur $(\mathrm{p}=0.008)$, ileri analizlerde $26-35$ ve $46-56$ yaş arasında $26-35$ yaş lehine $(\mathrm{p}=0.002), 36-45$ ve $46-56$ yaş arasında $36-45$ yaş lehine istatiksel olarak anlamlıdır $(p=0.04)$. Eğitim 
durumuna göre katılımcıların ÇHTÖ puan ortalaması ilk ögretim mezunları için $39.59 \pm 13.60$, lise mezunları için 35.66 \pm 9.82 , üniversite mezunlariç̧in $31.81 \pm 10.71$ olarak bulunmuştur $(\mathrm{p}<0.001)$. İleri analizlerde ilköğretim-lise-üniversite mezunları tüm gruplar arasında eğitim seviyesi artıkça istatiksel olarak anlamlı artış bulunmuştur $(\mathrm{p}<0.05)$. Çalışmanın yapıldığ 1 illere göre ÇHTÖ puan ortalaması Adana için $32.25 \pm 9.41$, Mersin için 33.34 \pm 11.47 , Manisa için $38.41 \pm 13.65$, Ordu için $37.30 \pm 10.6$, Ankara için $35.07 \pm 9.94$ olarak bulunmuştur $(\mathrm{p}=0.025)$. İleri analizlerde Adana-Manisa ve Adana-Ordu arasında
Adana lehine istatiksel olarak anlamlıdır $(\mathrm{p}<0.05)$. Mersin-Manisa ve Mersin-Ordu arasında Mersin lehine istatiksel olarak anlamlıdır $(\mathrm{p}<0.05)$. Sivil toplum örgütleri çalışanlarının ÇHTÖ puan ortalaması $33.79 \pm 10.65$, liderlerin puan ortalamas $36.43 \pm 12.25$ olarak bulunmuştur istatiksel olarak anlamlı değildir $(\mathrm{p}>0.05)$. Katılımcıların iş tecrübesine göre ÇHTÖ puanı ortalaması, 0-5 yıllık tecrübe için $33.20 \pm 8.97$, 610 yıl tecrübe için $32.73 \pm 9.54,11$ ve üzeri yıl tecrübe için $35.87 \pm 12.31$ olarak bulunmuştur $(\mathrm{p}>0.05)$ (Tablo 2) (Tablo 3).

\section{Tablo 2. Sivil toplum örgütü çalışanlarının sosyo-demografik verilerine göre ÇHTÖ puanları}

Gruplar (n)

Sayı (n) Ortalama

88

32.23

\begin{tabular}{|c|c|c|c|c|c|}
\hline \multirow[t]{2}{*}{ Cinsiyet (275) } & Erkek & 187 & 36.12 & 12.14 & \multirow[t]{2}{*}{$0.008^{*}$} \\
\hline & Kadın & 88 & 32.23 & 9.10 & \\
\hline \multirow[t]{2}{*}{ İş (275) } & Başkan & 113 & 36.43 & 12.25 & $0.058 *$ \\
\hline & Çalışan & 162 & 33.79 & 10.65 & \\
\hline \multirow[t]{3}{*}{ Tecrübe (275) } & $0-5$ y1l & 55 & 33.20 & 8.97 & $0.137 * *$ \\
\hline & $6-10$ yil & 40 & 32.73 & 9.54 & \\
\hline & $11+\mathrm{y} 1 \mathrm{l}$ & 180 & 35.87 & 12.31 & \\
\hline \multirow[t]{4}{*}{ Yaş (275) } & $18-25$ yaş & 12 & 31.67 & 9.45 & $0.008 * *$ \\
\hline & 26-35 yaş & 54 & 31.48 & 9.15 & \\
\hline & 36-45 yaş & 89 & 34.08 & 11.29 & \\
\hline & 46-56 yaş & 120 & 37.88 & 12.09 & \\
\hline \multirow[t]{5}{*}{ İller (275) } & Adana & 51 & 32.25 & 9.41 & $0.025 * *$ \\
\hline & Mersin & 94 & 33.34 & 11.47 & \\
\hline & Manisa & 51 & 38.41 & 13.65 & \\
\hline & Ordu & 37 & 37.30 & 10.6 & \\
\hline & Ankara & 42 & 35.07 & 9.94 & \\
\hline \multirow[t]{3}{*}{ Eğitim durumu (275) } & İlköğretim & 56 & 39.59 & 13.60 & $0<001 * *$ \\
\hline & Lise & 106 & 35.66 & 9.82 & \\
\hline & Üniversite & 113 & 31.81 & 10.71 & \\
\hline
\end{tabular}

162

33.79

10.65

$( \pm)$

*Students's t testi, **One-wayAnova 


\begin{tabular}{|c|c|c|c|c|c|}
\hline Gruplar & $\begin{array}{l}\text { Alt gruplar } \\
\text { (I) }\end{array}$ & $\begin{array}{r}\text { Alt gruplar } \\
(J)\end{array}$ & $\begin{array}{c}\text { Ortalama farkı } \\
\text { (I-J) }\end{array}$ & Sh & $\mathbf{p}$ \\
\hline \multirow[t]{6}{*}{ Yaş } & $26-35$ yaş & $18-25$ yaş & -0.185 & 3.577 & 0.959 \\
\hline & & $36-45$ yaş & -2.597 & 1.933 & 0.180 \\
\hline & & $46-56$ yaş & $-5835^{*}$ & 1.836 & $0.002 *$ \\
\hline & $36-45$ yaş & $18-25$ yaş & 2.412 & 3.446 & 0.485 \\
\hline & & $26-35$ yaş & 2.597 & 1.933 & 0.180 \\
\hline & & $46-56$ yaş & $-3.238^{*}$ & 1.568 & $0.040^{*}$ \\
\hline \multirow[t]{8}{*}{ İller } & Adana & Mersin & -1.086 & 1.955 & 0.579 \\
\hline & & Manisa & $-6.157^{*}$ & 2.226 & $0.006^{*}$ \\
\hline & & Ordu & $-5.042 *$ & 2.428 & $0.039^{*}$ \\
\hline & & Ankara & -2.817 & 2.343 & 0.230 \\
\hline & Mersin & Adana Manisa & 1.086 & 1.955 & 0.579 \\
\hline & & Ordu & $-5.071^{*}$ & 1.955 & $0.010^{*}$ \\
\hline & & Ankara & -3957 & 2.182 & 0.071 \\
\hline & & & -1.731 & 2.087 & 0.408 \\
\hline \multirow[t]{4}{*}{ Eğitim durumu } & İlköğretim & Lise & $3.929 *$ & 1.825 & $0.032 *$ \\
\hline & & Üniversite & $7.784^{* *}$ & 1.805 & $0.000^{* *}$ \\
\hline & Lise & Üniversite & $3.855^{* *}$ & 1.493 & $0.000^{* *}$ \\
\hline & & İlköğretim & $-3.929 *$ & 1.825 & $0.032 *$ \\
\hline
\end{tabular}

OneWayAnovaPosthoc-LSD, ${ }^{*} \mathrm{p}<0.05, * * \mathrm{p}<0.001$

Sh: Standart hata

\section{TARTIŞMA}

Çocuk işçiliği, gelişimsel ihtiyaçları dikkate alındığında çocuğu mağdur eden, pek çok olumsuz sonuçlar ortaya çıkaran küresel bir konudur. ${ }^{4,8,10,12} \mathrm{Bu}$ bağlamda çocuğun sadece bulunduğu gelişimsel dönemdeki aile, eğitim, sağlık ve sosyal yaşam örüntüsünü değil, daha sonraki hayatında da tüm alanlarda kompleks bir etki oluşturduğu bilinmektedir. Sağlık açısından çocuğun şimdiki ve ilerideki yaşamında, mental sağlıktan fiziksel sağlığa, çocuğun olumsuz etkilendiğini gösteren araştırmalar mevcuttur 12,20,21 Sağlık bakım profesyonelleri özellikle hemşireler ve doktorlar, toplum ve aile arasında çocuk işçiliğine karş1 bilinçlendirmede önemli bir güçlendirici bağ oluşturabilir. Çocuk haklarının korunması, çocuk iş̧iliğinin sağlık üzerine etkileri ve farkındalık araştırmalarının yapılması hemşire ve diğer sağlık profesyonellerinin önemli bir sorumluluk yüklemektedir. ${ }^{1,11}$
Multidisipliner bir bakış açısıyla yapılan bu araştırmada katılımcıların çocuk hakları, çocuk işçiliği nedenleri ve bağlayıcı kanunlar hakkında farkındalık düzeylerini; sivil toplum örgütlerinde yönetici olmak, üniversite düzeyinde eğitim almak, 11 yll ve üzerinde iş tecrübesine sahip olmanın, farkındalığ bulunmuştur. Bakır'ın (2008) çocuk işçiliğinin nedenlerini içine alan, toplumsal bilinç düzeyinin ölçülmesine yönelik araştırmasında, katılımcıların yarısının, çocukların ağır sanayi işlerinde, aile işçisi olarak ya da sokakta çalıştırılması ve çocuk hakları konularında bilgi sahibi olmadıkları belirlenmiştir. ${ }^{18}$ Başka bir araştırma sonuçlarına göre, sivil toplum örgütlerinin işveren olarak, çocuk işçiliği nedenlerini bilmesi, yasal mevzuatı bilmesi halinde ancak çocuk çalışma koşullarının iyileştirilebileceği önerilmiştir. ${ }^{17}$ Çocuk işçiliği nedenlerini ve yasal mevzuatı bilme durumu, katılımcıların eğitim düzeyi, tecrübe yılı ve iş pozisyonu ile artmaktadır. Çocuk haklarını dikkate alarak gerçekleşen, yasal dayanaklar çerçevesinde 
sınırlanan çocuk işçiliği, aile ve işverenin bu konuda bilinçli hale getirilmesi ile sağlanabilir. ${ }^{14}$

Araştırma sonuçlarına göre çocukların erken yaşta işe başlamasından, hafif ev işleri dahil çocuk işçiliğine yönelik bakış açılarını cinsiyet, iş pozisyonu, iş tecrübesi, yaş, eğitim ve iller etkilemektedir. Bu veriler, çocukların erken yaşta işe başlamasını erkeklerin, yöneticilerin, 11 y1l ve üzerinde tecrübesi olanların, 4656 yaş aralığındakilerin ve lise mezunu katılımcıların desteklediği göstermektedir. Araştırma bulguları, lise mezunu katılımcılar lehine, 15 yaş altı çocukların hafif ev işleri dışında hiçbir şekilde çalıştırılmaması gerektiğini desteklemektedir. Öte yandan gida, metal, tarım, tekstil sektörlerinde çalışan 36-45 yaş grubu işçilerle yapılan araştırmada, işçilerin \%80'i çocukların erken yaşta çalıştırılabileceği görüşüne katılmamaktadır. ${ }^{18}$ İşverenler ve çalışan işçilerde yapılan iki farklı araştırma sonuçları, çocuklarınn erken yaşta çalışmasına iki grubun farlı yönde baktığını altına çizen önemli bir sonucu ortaya koymaktadır.Adonteng$\mathrm{Kissi}^{14}$ yaptığ 1 araştırmada, çocuk işçiliğinin yaş, toplumsal cinsiyet, kültürden etkilendiğini belirtmiş, araştırmasında katılımcı olarak ailelerin, çocukların hakları dikkate alınarak çalışmasını, çocuk işçiliğini sosyalleşme olarak gördüklerini ve desteklediklerini bulmuştur. Benzer şekilde Lachowski ve Zagorski (2011) Polonya'da yaptıkları araştırmada, ailelerin çocuk işçiliğine bakış açıları değerlendirilmiş, ailelerin çocuklarını, ev işlerinde ve tarımda çalışmasının aileler tarafından desteklendiği bulunmuştur. ${ }^{13}$

Katılımcıların çocuk haklarının yaygınlaştırılması, çocuk işçiliğinde sorumluluk almasını içeren verilere göre erkek cinsiyet, üniversite düzeyinde eğitim, yönetici olmak, 26-35 yaş aralığı, bölgesel olarak Mersin ili çocuk haklarının yaygınlaştırılmasında, diğer gruplara oranla anlamlı artış göstermektedir. Katılımcıların çocuk işçiliği hakkında daha önceki faaliyetlerde, üniversite düzeyinde eğitim sahibi olanların, yöneticilerin daha fazla katıldığını göstermektedir. $\mathrm{Bu}$ bulgu olanakların bu grupta daha erişilebilir olması ile ilgili olabilir.Omokhodion ve Uchendu (2010), Nijerya'da yaptıkları çalışmada, ailelerin, çocuk işçiliğinin nedenleri, çocuğa olumsuz etkilerine yönelik farkındalıkları olmasına rağmen yoksulluk nedeniyle çocuklarını çalıştırdıklarını bulmuştur. Kadınların ve büyük ailelerin, çocuk işçiliğini daha çok desteklediğini gösteren verilerde, aslında farkındalık yüksek olsa bile yoksulluğun, çocuk işçiliğinde durumu değiştirmediğine işaret etmektedir. Araştırma verileri, çocuk işçiliği bilgilendirme ve eğitim faaliyetlerinin daha çok kadınlar ve büyük aile fertleri üzerinde yoğunlaşmasına dikkati çekmektedir. ${ }^{2}$ Sivil toplum örgütleri ve meslek kuruluşlarının işverenin gözetim ve denetimi altındaki çocuğun tüm sorumluluğunu alması, çocuğun kullandığı tüm aletlerin çocuğa uygunluğu kontrol edilerek muhtemel risklerine karşı önlem alınması önerilmektedir. ${ }^{17}$ Bahadır ve Uçku (2016) araştırmasında, Suriyeli çocukların çocuk işçiliği durumu incelemiş, çocukların çalışma hayatına katılmalarının, çocukları eğitimden uzak tutarak çocuk haklarını sınırladığını aynı zamanda fiziksel, ruhsal ve sosyal gelişimlerini olumsuz etkilediğini belirtmiştir. Çocukların çalışma ortamının denetlenmesi gerekmektedir. Yasal ülke politikalarının çocuk haklarına gore düzenlenmesi, yeniden gözden geçirilerek, çocuk işçiliğinde yönetimlere sorumluluk yüklemektedir. $^{20}$ Lordoğdu ve Aslan (2018) çalışmasında, yasal düzenlemelerin çocukların çalışma koşullarında ve işverenlerin istismarına karş1 korunmalarında önemini vurgulamıştır. ${ }^{8}$ Al-Gamal ve Hamdan-Mansour (2013)araştırmasındada aynı şekilde ulusal ve uluslararası yaklaşımların, yasal ve politik güçlerin devreye girmesi, sorumluluğu devletin alması ve gelecekte sorunların çözümünde etkili olacağ yönündedir. ${ }^{10}$ Nafees ve Khan (2012) Pakistan'da yaptığı çalışmada benzer şekilde sivil toplum örgütleri ile daha çok işbirliği içeren çalışmalara ihtiyaç duyulduğunu, yasa ve mevzuatların daha fazla çocuk yanlısı açılımlarına ve çocuk işçiliğinde yer alan tüm paydaşlara sorumluluk vermektedir. ${ }^{3}$ Özetle literatür, sorumluluk alması gereken liderlerin, çocuk haklarını bilmesi gereği kadar, yasal olarak bağlayıcı ve denetleyici önlemler alınmasınıda vurgulamaktadır.

$\mathrm{Bu}$ araştırmada sivil toplum örgütleri çalışanlarının ÇHTÖ puan ortalaması $33.79 \pm 10.65$, liderlerin puan ortalaması $36.43 \pm 12.25$ olarak bulunmuştur. Katılımcıların çocuk hakları tutumlarını kadın olmak, 26-35 yaş, üniversite mezunu olmak, sivil toplum örgütlerinin bölgesel olarak Adana ilipozitif yönde etkilemektedir. Karaman Kepenekçi (2009) yaptığ1 çalışmada farklı eğitim verdikleri gruplarda, çocuk hakları tutum puanını 27.60 ile 31.39 arasında bulmuştur. $^{22}$ Bulgular, çocuk ve insan haklarına ilişkin eğitim almanın çocuk haklarına ilişkin tutumlarını olumlu yönde geliştirdiğini desteklenmektedir. Yurtsever Kılıçgün ve Oktay (2009) çocuk hakları tutumunun kültürel ve sosyal değişkenlerden etkilendiğini, bu alanda yapılacak araştırmalara gereksinim duyulduğunu belirtmiştir. ${ }^{23}$ Diğer bir araştırma, ebeveynlerin çocuk hakları tutumlarının eğitim, gelir düzeyi,doğup büyünen yer gibi değişkenlerden etkilediğini göstermektedir. ${ }^{24}$ Kissi'nin (2018) Gana'da yaptığı araştırma ebeveynlerin, çocukların çalışması ancak insan hakları ve Birleşmiş milletler çocuk hakları sözleşmesine (UNCRC) bağlı kalarak onayladıklarını ve desteklediklerini göstermektedir. ${ }^{14}$

\section{SONUÇ}

Literatür bilgilerine göre bu sonuçlar, çocuk işçiliğini farklı yönleriyle ortaya koyarken, insan hakları, çocuk hakları, yasal mevzuatlarla çocuk haklarını koruyan, sinırlayan ve sorumluluğu tüm paydaşlara dağıtan çocuk işçiliğine daha kabul edilebilir bir bakış açısı sunmaktadır. Küresel ve disiplinlerarası bir sorun olarak çocuk işçiliği, çocukların sağlığının gelişebilmesi içinsağlık profesyonellerine, mevcut ve 
potansiyel sağlık risklerini ortaya koyarak, çocukların sağlıklı gelişmesini destekleyen, çocuk hakları toplumsal bilinç düzeyini ölçen araştırmalardabu bağlamda sorumluluk ve önemli roller vermektedir.Sonuç olarak, işveren olarak sivil toplum örgütlerinin çocuk işçiliğinde çocuk hakları tutumları ortaya konmuş; çocuk işçiliğine neden olan faktörlerin düzeltilmesi, katılımcıların farkındalık düzeylerine göre, çocuk haklarını korumaya yönelik önlemler oluşturulması ve çocuk iş koşullarının düzeltilmesinde önemli sonuçlara dikkat çekilmiştir.

\section{KAYNAKLAR}

1. Gulzar S, Vertejee S, Pirani L. Child labour: A public health issue. J Pak Med Assoc. 2009;59(11):778-81.

2. Omokhodion FO, Uchendu OC. Perception and practice of child labour among parents of school-aged children in Ibadan, southwest Nigeria. Child Care Hlth Dev. 2010;36(3):304-8.

3. Nafees AA, Khan KS, Fatmi Z, Aslam M. Situation analysis of child labour in Karachi, Pakistan: a qualitative study. Journal of the Pakistan Medical Association. 2012;62(10):1075-82.

4. Efe H, Uluoğlu SA. Dünyada Çocuk İşçiliğiyle Mücadelede Gelinen Nokta ve Geleceğe Dair Bazı Öngörüler. Eğitim Bilim Toplum Dergisi 2015;13(51):46-72.

5. Global Estimates of Child Labour: Results and trends, 2012-2016 [Internet]. ILO. 2017 [cited https://www.ilo.org/global/publications/books/WCMS 575499/lang--en/index.htm].

6. Çocuk İşgücü Anketi Sonuçları, 2012 [Internet]. 2012 [cited http://www.tuik.gov.tr/PreHaberBultenleri.do?id=13659 ].

7. Türkiye İstatistik Kurumu 2018 y1lı çocuk istatistikleri [Internet]. 2018 [cited https://bianet.org/bianet/cocuk/207629-tuik-verilerinegore-cocuk-isci-sayisi-artti].

8. Lordoğdu K, Aslan M. Görünmeyen Göçmen Çocukların İşçiliği: Türkiye'deki Suriye'li Çocuklar. Çalışma ve Toplum. 2018;2:715-32.

9. Tor H. Türkiye'de Çocuk İşçiliğinin Boyutları Zeitschrift für die Welt der Türken. 2010;2(2):25-42.

10. Al-Gamal E, Hamdan-Mansour AM, Matrouk R, Al Nawaiseh M. The psychosocial impact of child labour in Jordan: A national study. Int $\mathrm{J}$ Psychol. 2013;48(6):1156-64.
11. Aydın D, Şahin N, Akay B. Göç olayının çocuk sağlığı üzerine etkileri. İzmir Dr Behçet Uz Çocuk Hast Dergisi. 2017;7(1):8-14.

12. Sturrock S, Hodes M. Child labour in low- and middle-income countries and its consequences for mental health: a systematic literature review of epidemiologic studies. European child \& adolescent psychiatry. 2016;25(12):1273-86.

13. Lachowski S, Zagorski J. Child labour for the benefit of the family in rural Poland. Ann Agr Env Med. 2011;18(2):386-92.

14. Adonteng-Kissi O. Parental perceptions of child labour and human rights: A comparative study of rural and urban Ghana. Child Abuse Neglect. 2018;84:34-44.

15. Child Labor, Education, and Children's Rights [Internet]. Human Development Network The World Bank. 2004 [cited http://documents.worldbank.org/curated/en/7210614687 62634105/Child-labor-education-and-childrens-rights].

16. Turner-Moss E. Child labour must be on the post2015 agenda. Lancet. 2013;382(9910):E52-E3.

17. Küçükkalay M, dulupçu MA, Turunç Ö. Dünya'da ve Türkiye'de Çocuk İşgücü İstihdamının Sorunları ve Önlenmesi. Süleyman Demirel Üniversitesi İktisadi ve İdari Bilimler Fakültesi. 2000;5(1):103-18.

18. Bakır YE. Türkiye'de Çocuk İşçiliği Sorununda Toplumsal Bilinç Düzeyinin Ölçülmesi (Yüksek Lisans tezi). Ankara Üniversitesi, Sosyal Bilimler Enstitüsü, Ankara; 2008;29-41.

19. Karaman Kepenekçi Y. A study of university studets' attitudes towards children's rights in Turkey. The International Journal of Children's Rights. 2006; 14:307-19.

20. Bahadır H, Uçku R. İzmir'in Bir Mahallesinde Yaşayan 6-17 Yaş Arasındaki Suriyeli Çocukların Çalışma Durumları ve Çalışma Durumlarını Etkileyen Etmenler. DEÜ Tıp Fakültesi Dergisi. 2016;30(3):11724.

21. Lasgaard M, Lindekilde N, Bramsen RH. Patterns of victimization: A person-centered approach to physical and sexual violence in a representative sample of Danish youth. Child Abuse Neglect. 2018;84:115-22.

22. Karaman Kepenekçi Y. Zihin Engelliler Öğretmen Adaylarinin Çocuk Haklarina İlişkin Tutumlari. Ankara Üniversitesi Eğitim Bilimleri Fakültesi Dergisi. 2009;42(1):329-50.

23. Yurtsever Kılıçgün M, Oktay A. Çocuk Haklarına Yönelik Ebeveyn Tutum Ölçeğinin Geliştirilmesi ve 
Standardizasyonu. Buca Eğitim Fakültesi Dergisi. 2011;31:1-22.

24. Yurtsever M. Ebeveyn Çocuk Haklari Tutum Ölçeğinin Geliştirilmesi ve Anne Babaların Çocuk
Haklarına Yönelik Tutumlarının Farklı Değişkenler Açısından İncelenmesi (Doktora Tezi). Marmara Üniversitesi, Eğitim Bilimleri Enstitüsü; 2009;72-112. 